\title{
Characteristics of Bread Made of Various Substitution Ratios of Bran Pulverized by Hammer Mill or Jet Mill
}

\author{
Dabeen Lee ${ }^{1}$, Mi Jeong Kim ${ }^{2}$, Han Sub Kwak ${ }^{1}$ and Sang Sook Kim ${ }^{1, *}$ \\ 1 Research Group of Food Processing, Korea Food Research Institute, Jeollabuk-do 55465, Korea; \\ Lee.Da-been@kfri.re.kr (D.L.); hskwak@kfri.re.kr (H.S.K.) \\ 2 Department of Food and Nutrition, Changwon National University, Changwon-si 51140, Korea; \\ mjkim@changwon.ac.kr \\ * Correspondence: sskim@kfri.re.kr; Tel.: +82-603-219-9042; Fax: +82-603-219-9876
}

Received: 31 October 2019; Accepted: 17 December 2019; Published: 4 January 2020

\begin{abstract}
The physicochemical and antioxidant properties of dough and bread were measured in wheat flours substituted with two types of bran (HMB: bran pulverized by a hammer mill and JMB: bran pulverized by a jet mill) at various ratios $(0 \%, 5 \%, 10 \%, 15 \%, 20 \%$, and $25 \%)$ of substitution. The particle size of hammer mill bran (HMB) $(119.71 \mu \mathrm{m})$ was larger than that of jet mill bran (JMB) $(25.78 \mu \mathrm{m})$. Wheat flours substituted with HMB contained more total dietary fiber than those with JMB. A significant increase of water absorption and dough development time in Mixolab ${ }^{\circledR}$ analysis was observed depending on the level of HMB or JMB substitution. The breads made with HMB or JMB (5\% or $10 \%)$ showed a higher specific volume and lower crumb hardness than the control bread. However, breads made with $\geq 15 \%$ HMB or JMB had a decreased specific volume and increased crumb hardness. Overall, breads made with wheat flour substituted with 5\%-10\% HMB or JMB were of a higher bread quality and had more antioxidant properties.
\end{abstract}

Keywords: bran milling; hammer mill; jet mill; bran substitution ratio; bread quality

\section{Introduction}

The most important cereal crop suitable for bread is wheat [1]. Wheat consists of three main parts: germs, bran, and endosperm [2]. Wheat flour has a different nutrient composition depending on the extraction rate during milling. Refined wheat flour, produced when the extraction rate is below $75 \%$, is the best type for baking, but it has fewer health benefits than whole wheat flour [1].

Wheat bran is usually eliminated as a byproduct during milling for refined wheat flour, and is used as animal feed. However, the demand for bran is increasing in modern society due to interest in its health benefits: it is richer in nutrients, such as proteins, fat, vitamins, and minerals, than ordinary refined wheat flour, and it contains a variety of physiologically active components [3-5].

Bran also contains a large amount of dietary fiber. Proper intake of dietary fiber reduces the risk of obesity, cardiovascular disease, and type 2 diabetes as well as reduces intestinal passage time [6,7]. Therefore, numerous attempts have been made to incorporate wheat bran into various foods, such as pasta [8-10], noodles [11], doughnuts [12], and biscuits [13].

In many countries, bread is a staple food, so much effort has been made to optimize the quality of bran-rich bread [14]. However, information on the effects of milling methods and substitution ratios of bran on bakery products is limited. Therefore, the aim of this study was to investigate the effects of milling methods on the characteristics of bran and the effects of the substitution ratio of bran on the properties of bread. 


\section{Materials and Methods}

\subsection{Materials}

Bran and flour were provided by CJ Cheiljedang (Seoul, Korea). All reagents used in the analysis were purchased from Sigma-Aldrich Inc. (St. Louis, MO, USA). The wheat bran with 16.64\% moisture content was dried to a moisture content of about $6 \%$ at $40{ }^{\circ} \mathrm{C}$ using a dry oven (HK-DO1000F, Hankuk S\&I Co., Hwaseong, Korea) and then milled using a hammer mill (Daega Powder System Co., Ltd., Seoul, Korea) or air jet mill (Daega Powder System Co., Ltd., Seoul, Korea). The milling conditions were as follows: Bran was pulverized by the hammer mill mounted with a $300 \mu \mathrm{m}$ sifter at a speed of $40 \mathrm{~m} / \mathrm{s}$. The air jet mill was run under air pressure of 8 bar with a feed rate of $0.71 \mathrm{~kg} / \mathrm{h}$ and a vibration rate of the feeder of $70 \%$. The wheat bran pulverized with the hammer mill or air jet mill replaced $0 \%$, $5 \%, 10 \%, 15 \%, 20 \%$, and $25 \%$ of the wheat flour weight.

\subsection{Chemical Analysis}

The contents of moisture ash and protein were analyzed by American Association of Cereal Chemists (AACC) Method 44-15A, 08-01, 46-12 (AACC, 2010) respectively, the wet gluten content was determined by the Glutomatic ${ }^{\circledR}$ system (Glutomatic 2200, Perten Instruments, Hagersten, Sweden) as in AACC method 38-12A, and the dietary fiber content was analyzed according to AACC Method 32-07. Starch damage was measured according to AACC Method 76-31 (AACC, 2010) using the Damaged Starch Analyzer (SDmatic, Chopin Technologies, Villeneuve La Garenne, France). The L (lightness) value, the a (redness) value, and the $b$ (yellowness) value were measured using the spectrophotometer CM-700d (Konica Minolta Sensing Americas, Inc, Ramsey, NJ, USA). Particle size was measured by the Particle Size Analyzer 1190 (CILAS, Orléans, France).

\subsection{Microstructure of Bran and Dough with Various Substitution Ratios of Bran by Scanning Electron Micrograph (SEM)}

The microstructure of bran and dough with various ratios of bran was investigated by SEM (S-2380, Hitachi, Tokyo, Japan). The bran and dough were dehydrated as in Inoue and Osatake [15]. The bran or slice of dehydrated dough was placed on an adhesive tape attached to a circular aluminum specimen stub and coated with gold-palladium using Hitachi E-1010 10 N sputter coater (Tokyo, Japan) and photographed at an accelerator potential of $15 \mathrm{kV}$ using SEM.

\subsection{Evaluation of Dough Characteristics}

Mixolab $^{\circledR}$ is a device that measures the characteristics of wheat flour by measuring the torque of the dough as the temperature rises [16]. As dough characteristics, water absorption, lowest viscosity (C2), and maximum viscosity corresponding to starch gelatinization (C3), stability (C4), development time, and retrogradation (C5) of wheat flour were measured using the Mixolab (Chopin, Tripetteet Renaud, Paris, France). The flour was placed in the Mixolab ${ }^{\circledR}$ bowl and water was added to reach a dough consistency (C1) value of $1.1 \mathrm{Nm}$. Dough development time, indicating the hydration rate of the dough, is the time required for each sample to reach $C 1$, which is an objective value of $1.1 \mathrm{Nm}$ on average. The stability time of the dough indicates the time to maintain a 1.1 torque value. The conditions according to 'Chopin $+{ }^{\prime}$ protocol are as follows: keep the dough at $30^{\circ} \mathrm{C}$ for 8 min while mixing, then heat to $90^{\circ} \mathrm{C}$ at the rate of $4^{\circ} \mathrm{C} / \mathrm{min}$ for $15 \mathrm{~min}$. After reaching $90^{\circ} \mathrm{C}$, the temperature was kept constant for $7 \mathrm{~min}$, and cooled to $50{ }^{\circ} \mathrm{C}$ at the rate of $4^{\circ} \mathrm{C} / \mathrm{min}$ for $5 \mathrm{~min}$. 


\subsection{Preparation of Bread and Physical Characteristics of Bread}

The bread was made by the modified AACC Method 10-10B (AACC, 2010): 100\% of flour, optimum water, $5.3 \%$ of yeast, $6 \%$ of sucrose, $1.5 \%$ of salt, $3 \%$ of shortening, and $0.2 \%$ of baking improver (Excel, Sunjin, Chungnam, Korea) were added instead of malt flour, ascorbic acid, and potassium bromate. The amount of water added for bread dough was determined based on the water absorption value by Mixolab ${ }^{\circledR}$. The volume, weight, and specific volume of the bread were measured using the Volscan profiler (Stable Micro System Ltd., Haslemere, UK). The hardness of the bread crumb was measured by the modified AACC Method 74-09 (AACC, 2010) with the Texture Analyzer TA-XT plus (Stable Micro System Ltd., Haslemere, UK). The crumb was cut to width $\times$ length $\times$ height of $25 \times 25 \times 19 \mathrm{~mm}$, respectively and compressed by approximately $40 \%$ using a $36 \mathrm{~mm}$ plunger. The return distance was $30 \mathrm{~mm}$, the return speed was $10 \mathrm{~mm} / \mathrm{s}$, and the contact force was $50 \mathrm{~g}$.

\subsection{Free Phenolic Compounds Extraction}

The free phenolic compounds of bread were extracted based on the method of Lim et al. [17] with some modifications. The freeze-dried bread $(1 \mathrm{~g})$ was extracted with $80 \%$ chilled ethanol $(20 \mathrm{~mL})$, and the mixture was centrifuged at $8000 \mathrm{rpm}$ for $20 \mathrm{~min}$. After centrifugation, the supernatant was collected, and the residue was extracted with the above procedure twice. The ethanol extract was concentrated using a vacuum evaporator (HS-2001N, Hahnshin S\&T Co., Gimpo, Korea), and then dissolved in $10 \mathrm{~mL}$ of $80 \%$ ethanol. The ethanol extract was stored at $-20^{\circ} \mathrm{C}$ for analysis.

\subsection{2,2'-Azino-bis (3-ethylbenz-thiazoline-6-sulfonic acid (ABTS) Radical Scavenging Activity}

ABTS radical scavenging activity was determined by a modified version of the method of Rosa et al. [18]. The samples $(40 \mu \mathrm{L})$ were mixed with ABTS radical solution $(1960 \mu \mathrm{L})$, they reacted for $6 \mathrm{~min}$, and absorbance was measured at $734 \mathrm{~nm}$. Each sample activity was expressed in $\mu \mathrm{mol}$ Trolox equivalents (TE)/g.

\subsection{Oxygen Radical Absorbance Capacity (ORAC) Assay}

ORAC assay was determined based on the method of Moore et al. [19]. The samples $(20 \mu \mathrm{L})$, fluorescein solution in $75 \mathrm{mM}$ phosphate buffer $(\mathrm{pH} 7.4)(200 \mu \mathrm{L})$ and $79.6 \mu \mathrm{M} \mathrm{AAPH}$ (2,2'-azobis(2-amidino-propane) dihydrochloride) $(20 \mu \mathrm{L})$ were dispensed into a 96-well microplate. After mixing, the fluorescein intensity was measured at excitation of $485 \mathrm{~nm}$ and emission of $520 \mathrm{~nm}$ (at 1-min intervals) using a Spectra Max ${ }^{\circledR}$ i3 (Molecular Devices, San Jose, CA, USA) equipped with an incubator at $37^{\circ} \mathrm{C}$ for $90 \mathrm{~min}$. The result was calculated as the difference between the fluorescein intensity of the sample and the fluorescence intensity of the blank. Trolox was used as the standard material.

\subsection{Statistical Analysis}

Mixolab $^{\circledR}$ assay was conducted in duplicate, the others were conducted in triplicate, and the results were expressed as mean \pm standard deviation. Statistical analysis was performed using SPSS 20 (Chicago, IL, USA) software. The effects of the milling methods on the particle size of the bran were analyzed by Student's $t$-test. Analysis of variance (ANOVA) was carried out to determine the differences in the characteristics of the flour, dough, and bread samples with the different substitution ratios of bran. Duncan's multiple comparison test was performed to determine the significant differences between treated means $(p \leq 0.05)$. 


\section{Results and Discussion}

\subsection{Composition of Wheat Bran Pulverized by a Hammer Mill or Jet Mill and that of Wheat Flour Substituted} with Various Ratios of Bran

The particle size and color of bran pulverized by a hammer or jet mill are shown in Table 1. The particle size of jet mill bran (JMB) was significantly smaller than that of hammer mill bran (HMB) $(p \leq 0.05)$. The air jet mill is a relatively recent technology for milling, and the hammer mill is a traditional impact mill. Pulverization by the air jet mill is made by injecting compressed high-pressure air into a grinding chamber through a nozzle to generate a high-speed spiral air flow and then feeding the raw material into a chamber by a jet nozzle. After that, the suspended particles collide with each other and the particles are released when the particles are milled to the desired size [20]. The hammer mill pulverizes the cereals or objects with the simultaneous exertion of impact force, frictional force, compressive force, and shear force between the hammer and the liner rotating at high speed. The air jet mill achieves an accurate and narrow range of particle size. The hammer mill can control particle size and grind large quantities continuously [20].

Table 1. The particle size and color characteristics of bran pulverized by hammer mill or jet mill.

\begin{tabular}{ccccc}
\hline \multirow{2}{*}{ Type of Bran } & \multirow{2}{*}{ Mean Particle Size $^{* * *}(\mu \mathrm{m})$} & \multicolumn{3}{c}{ Color } \\
\cline { 3 - 5 } & & $\mathbf{L}^{* * *}$ & $\mathbf{a}^{* * *}$ & $\mathbf{b}^{* * *}$ \\
\hline Bran & $>150$ & $64.07 \pm 0.31^{\mathrm{c}}$ & $6.90 \pm 0.12^{\mathrm{a}}$ & $18.36 \pm 0.19^{\mathrm{b}}$ \\
HMB & $119.71 \pm 3.13^{\mathrm{a}}$ & $74.42 \pm 0.31^{\mathrm{b}}$ & $4.64 \pm 0.26^{\mathrm{b}}$ & $19.86 \pm 0.61^{\mathrm{a}}$ \\
JMB & $25.78 \pm 0.53^{\mathrm{b}}$ & $78.37 \pm 1.31^{\mathrm{a}}$ & $2.51 \pm 0.03^{\mathrm{c}}$ & $15.42 \pm 0.18^{\mathrm{c}}$
\end{tabular}

JMB: bran pulverized by jet mill, HMB: bran pulverized by hammer mill. All values are means of three replications \pm standard deviation. ${ }^{* * *}$ Indicates a significant difference at $p \leq 0.001$ and different characters $(\mathrm{a}, \mathrm{b}, \mathrm{c})$ in the same column indicate a significant difference at $p \leq 0.05$.

The results of the color value $(\mathrm{L}, \mathrm{a}$, and $\mathrm{b}$ ) analysis for bran showed that the $\mathrm{L}$ value of the JMB was higher than that of HMB (Table 1). The L, a, and b values were measured as a unit of color, which is represented by one value for brightness and two for color. The color of bran affects the final products with bran. The higher the L value the whiter the color. Therefore, bran pulverized by the jet mill was whiter than that pulverized by the hammer mill. As the particle size gets smaller, the lightness increases because the surface area that can reflect light increases [21]. However, the $a$ and $b$ values of JMB were significantly lower than those of HMB (Table 1). As the 'a' value of the sample increases from a negative value to a positive value, the color changes from green to red; as the ' $b$ ' value of a sample increases, the color changes from blue to yellow. This means that the higher the value of a and $b$, the more red and yellow the sample is [22].

The micro images and particle size distribution of bran are shown in Figure 1. Images obtained with scanning electron microscopy (SEM) showed that JMB was uniform in particle shape while HMB was uneven in particle shape, and the distribution of particle size of JMB was narrower than that of $\mathrm{HMB}$, as previously reported by Saravacos and Kostaropoulos [20].

Protein, wet gluten, ash, and total dietary fiber were significantly different depending on the bran substitution ratio (Table 2). As shown in Table 2, the protein content and wet gluten content of refined wheat flour (RWF) were $10.75 \%$ and $24.70 \%$, respectively. The ash and total dietary fiber content of RWF were $0.67 \%$ and $1.80 \%$, respectively. Bran is one of the outer parts of wheat, rich in dietary fiber and bioactive components [23]. The content of protein, ash, and dietary fiber increased with the substitution ratio of bran. Overall, the wet gluten content decreased with the substitution ratio of bran, while the protein, ash, and dietary fiber content increased with the substitution ratio of JMB or HMB. This is because protein, ash, and dietary fiber content were higher in the bran than RWF [24]. The L value tended to decrease with the substitution ratio of JMB or HMB, while $a$ and $b$ values tended to increase. The $b$ value for the $5 \%$ HMB substituted flour tended to increase, like other 
samples, but did not increase significantly (Table 2). Overall, the results of this study confirmed the report by Chen et al. [25], which showed increased a and b values by the addition of bran.

A
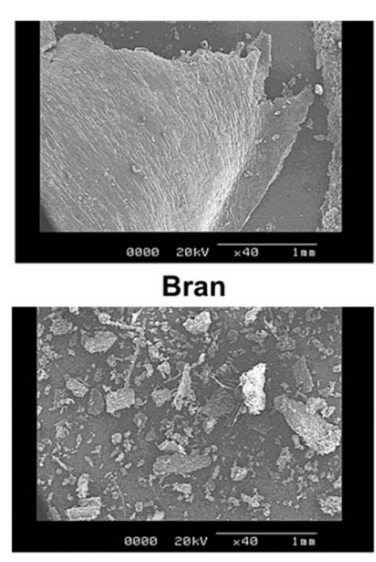

HMB

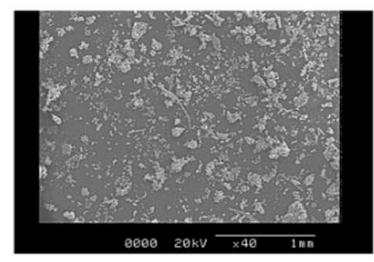

JMB
B
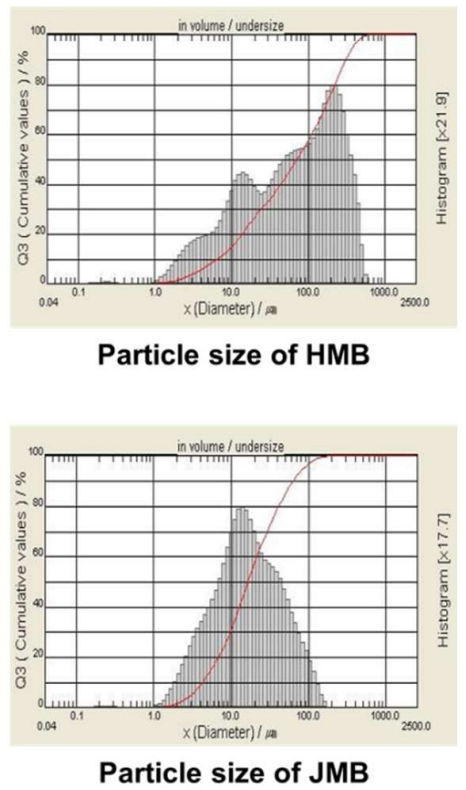

Figure 1. (A) Scanning electron microscopy (SEM, $\times 40)$ images and (B) particle size distribution of HMB or JMB. HMB: bran pulverized by hammer mill, JMB: bran pulverized by jet mill.

Table 2. Protein, TDF, wet gluten, ash, and color characteristics of flours substituted with HMB or JMB at various levels $(0 \%, 5 \%, 10 \%, 15 \%, 20 \%$, and $25 \%)$.

\begin{tabular}{|c|c|c|c|c|c|c|c|c|}
\hline \multirow{2}{*}{$\begin{array}{c}\text { Type of } \\
\text { Bran }\end{array}$} & \multirow{2}{*}{ Bran (\%) } & \multirow{2}{*}{$\begin{array}{l}\text { Protein }(\% \\
\text { db) }\end{array}$} & \multirow{2}{*}{$\begin{array}{l}\text { TDF }(\%, \\
\text { db) *** }\end{array}$} & \multirow{2}{*}{$\begin{array}{c}\text { Wet Gluten }(\%, \\
14 \% \mathrm{mb})\end{array}$} & \multirow{2}{*}{$\begin{array}{l}\text { Ash }(\%, \\
\text { db) *** }\end{array}$} & \multicolumn{3}{|c|}{ Color } \\
\hline & & & & & & $\mathbf{L}^{* * *}$ & $a^{* * *}$ & $\mathbf{b}^{* * *}$ \\
\hline RWF & 0 & $10.75 \pm 0.04^{h}$ & $1.80 \pm 0.19^{j}$ & $24.70 \pm 0.15^{a}$ & $0.67 \pm 0.10^{\mathrm{h}}$ & $94.24 \pm 0.35^{\mathrm{a}}$ & $0.27 \pm 0.03 \mathrm{~g}$ & $8.86 \pm 0.05^{\mathrm{e}}$ \\
\hline \multirow{5}{*}{ HMB } & 5 & $11.86 \pm 0.10 \mathrm{~g}$ & $4.01 \pm 0.34^{\mathrm{i}}$ & $23.05 \pm 1.12^{\mathrm{ab}}$ & $0.74 \pm 0.11$ gh & $91.97 \pm 0.56^{\mathrm{b}}$ & $0.89 \pm 0.10^{f}$ & $8.93 \pm 0.33^{e}$ \\
\hline & 10 & $12.25 \pm 0.06^{\mathrm{e}}$ & $7.19 \pm 0.37 \mathrm{~g}$ & $23.14 \pm 1.88^{\mathrm{ab}}$ & $1.10 \pm 0.07^{\mathrm{f}}$ & $91.55 \pm 0.44^{\mathrm{bc}}$ & $1.23 \pm 0.24$ de & $9.97 \pm 0.22^{d}$ \\
\hline & 15 & $12.56 \pm 0.06^{c}$ & $9.54 \pm 0.36^{\mathrm{e}}$ & $19.80 \pm 0.41^{\text {cde }}$ & $1.36 \pm 0.09$ de & $90.33 \pm 0.25^{\mathrm{cd}}$ & $1.68 \pm 0.24 \mathrm{bc}$ & $11.39 \pm 0.32^{c}$ \\
\hline & 20 & $12.86 \pm 0.02^{b}$ & $14.21 \pm 0.61^{b}$ & $18.26 \pm 0.52$ de & $1.61 \pm 0.04^{b c}$ & $88.57 \pm 1.19$ ef & $1.98 \pm 0.36^{\mathrm{a}}$ & $11.08 \pm 0.46^{c}$ \\
\hline & 25 & $13.17 \pm 0.12^{\mathrm{a}}$ & $15.61 \pm 0.22^{\mathrm{a}}$ & $18.79 \pm 0.27$ de & $1.88 \pm 0.13^{\mathrm{a}}$ & $88.44 \pm 0.55$ ef & $1.79 \pm 0.06^{\mathrm{ab}}$ & $10.96 \pm 0.44^{c}$ \\
\hline \multirow{5}{*}{ JMB } & 5 & $12.08 \pm 0.04^{f}$ & $2.42 \pm 0.47^{i}$ & $21.91 \pm 0.82^{\mathrm{abc}}$ & $0.73 \pm 0.08 \mathrm{gh}$ & $89.60 \pm 0.16^{d}$ & $0.88 \pm 0.06^{f}$ & $10.35 \pm 0.21^{\mathrm{d}}$ \\
\hline & 10 & $12.10 \pm 0.05^{\mathrm{e}}$ & $6.07 \pm 0.38^{h}$ & $20.55 \pm 0.96^{\text {bcde }}$ & $0.96 \pm 0.10 \mathrm{fg}$ & $89.11 \pm 0.39$ de & $1.16 \pm 0.04 \mathrm{e}$ & $11.34 \pm 0.03^{c}$ \\
\hline & 15 & $12.36 \pm 0.05$ de & $8.23 \pm 0.25^{f}$ & $20.64 \pm 1.74$ bcd & $1.16 \pm 0.05$ ef & $88.64 \pm 0.45^{\text {ef }}$ & $1.42 \pm 0.06^{\text {cde }}$ & $12.16 \pm 0.21^{b}$ \\
\hline & 20 & $12.51 \pm 0.05^{\mathrm{cd}}$ & $10.69 \pm 0.32^{\mathrm{d}}$ & $17.67 \pm 0.86^{\mathrm{e}}$ & $1.47 \pm 0.03^{\mathrm{cd}}$ & $88.24 \pm 0.18^{f}$ & $1.47 \pm 0.01^{\mathrm{cd}}$ & $12.22 \pm 0.07^{b}$ \\
\hline & 25 & $12.79 \pm 0.03^{b}$ & $13.12 \pm 0.13^{c}$ & $13.63 \pm 0.67^{f}$ & $1.84 \pm 0.02^{a b}$ & $87.84 \pm 0.61^{f}$ & $1.65 \pm 0.04 \mathrm{bc}$ & $12.87 \pm 0.10^{\mathrm{a}}$ \\
\hline
\end{tabular}

JMB: bran pulverized by jet mill, RWF: refined wheat flour, HMB: bran pulverized by hammer mill, TDF: total dietary fiber content. All values are means of three replications \pm standard deviation. Protein, TDF, and ash were calculated based on dry weight $(\mathrm{db})$. Wet gluten was calculated based on $14 \%$ moisture content $(\mathrm{mb})$. ${ }^{* *}$ Significantly differ at $p \leq 0.001$. Different characters $(\mathrm{a}-\mathrm{j})$ in the same column indicate a significant difference at $p \leq 0.05$.

\subsection{Dough Characteristics by Mixolab ${ }^{\circledR}$}

Dough characteristics measured by Mixolab ${ }^{\circledR}$ are outlined in Table 3. The water absorption of dough increased with the substitution ratio of $\mathrm{HMB}$ or JMB. The water absorption of wheat flour is affected by several factors. The water absorption of dough was increased by the addition of bran due to the water binding ability of bran. Since wheat bran competes with other major wheat flour components, such as starch and gluten, for water [26], a higher substitution ratio of bran might result in more water uptake, as shown in Table 3. The results of this study confirmed [27] that water absorption increases with the addition of dietary fiber to cereal flour. Increased water absorption with higher bran ratio in the white flour could be explained by the hydroxyl group in fiber that allows water binding $[16,28]$. 
Table 3. Water absorption, stability, and dough development by Mixolab ${ }^{\circledR}$ analysis of flours substituted with $\mathrm{HMB}$ or JMB at various levels $(0 \%, 5 \%, 10 \%, 15 \%, 20 \%$, and $25 \%)$.

\begin{tabular}{|c|c|c|c|c|c|c|c|c|c|}
\hline \multirow{2}{*}{$\begin{array}{l}\text { Type of } \\
\text { Bran }\end{array}$} & \multirow{2}{*}{$\begin{array}{c}\text { Bran } \\
(\%)\end{array}$} & \multicolumn{5}{|c|}{ Torque (Nm) } & \multirow{2}{*}{$\begin{array}{l}\text { Water Absorption } \\
(\%) * * *\end{array}$} & \multirow{2}{*}{$\begin{array}{l}\text { Stability } \\
\text { (min) }\end{array}$} & \multirow{2}{*}{$\begin{array}{l}\text { Dough Development } \\
\text { Time (min) }{ }^{* *}\end{array}$} \\
\hline & & $\mathrm{C} 11^{* *}$ & $\mathrm{C} 2$ *** & $\mathrm{C} 3 *$ & $\mathrm{C} 44^{* * *}$ & C5 ** & & & \\
\hline RWF & 0 & 1.12 bcde & $0.47^{\mathrm{d}}$ & $1.82^{\mathrm{d}}$ & $1.32^{\mathrm{c}}$ & $2.69 \mathrm{de}$ & $58.10 \pm 0.42^{\mathrm{e}}$ & $7.19 \pm 0.97$ & $1.70 \pm 0.49^{\mathrm{d}}$ \\
\hline \multirow{5}{*}{ HMB } & 5 & $1.08^{\mathrm{e}}$ & $0.50^{\mathrm{cd}}$ & $1.86^{\mathrm{bcd}}$ & $1.75^{\mathrm{ab}}$ & $3.06^{\mathrm{ab}}$ & $59.00 \pm 0.28^{\mathrm{e}}$ & $8.18 \pm 0.21$ & $2.73 \pm 0.94 \mathrm{bcd}$ \\
\hline & 10 & 1.12 bcde & $0.54 \mathrm{bc}$ & $1.91 \mathrm{abc}$ & $1.76^{\mathrm{a}}$ & $2.95^{a b c}$ & $61.05 \pm 0.64^{\mathrm{d}}$ & $8.18 \pm 0.18$ & $3.50 \pm 0.18 \mathrm{bcd}$ \\
\hline & 15 & $1.13^{b c d}$ & $0.54^{b c}$ & $1.91^{\mathrm{abc}}$ & $1.68^{\mathrm{ab}}$ & 2.71 cde & $62.55 \pm 0.78^{c}$ & $8.24 \pm 0.08$ & $3.51 \pm 0.20^{b c d}$ \\
\hline & 20 & $1.15^{\mathrm{abc}}$ & $0.57^{\mathrm{ab}}$ & $1.93^{a b}$ & $1.67^{\mathrm{ab}}$ & $2.72^{\text {cde }}$ & $64.15 \pm 0.49^{b}$ & $8.19 \pm 0.09$ & $5.06 \pm 0.18^{a b}$ \\
\hline & 25 & $1.20^{\mathrm{a}}$ & $0.60^{\mathrm{a}}$ & $1.96^{\mathrm{a}}$ & $1.64^{\mathrm{b}}$ & $2.73^{\text {cde }}$ & $65.40 \pm 0.42^{b}$ & $7.43 \pm 0.42$ & $6.33 \pm 0.22^{\mathrm{a}}$ \\
\hline \multirow{5}{*}{ JMB } & 5 & $1.10^{\mathrm{de}}$ & $0.50^{\mathrm{cd}}$ & $1.87 \mathrm{bcd}$ & $1.78^{\mathrm{a}}$ & $3.09^{a}$ & $59.15 \pm 0.35^{\mathrm{e}}$ & $7.95 \pm 0.14$ & $2.11 \pm 0.33^{\mathrm{cd}}$ \\
\hline & 10 & $1.10^{\text {cde }}$ & $0.47^{\mathrm{d}}$ & $1.84^{\mathrm{cd}}$ & $1.75^{\mathrm{ab}}$ & $3.03^{a b}$ & $60.85 \pm 0.35^{\mathrm{d}}$ & $7.82 \pm 0.69$ & $3.54 \pm 0.23 \mathrm{bcd}$ \\
\hline & 15 & $1.16^{\mathrm{ab}}$ & $0.48^{\mathrm{d}}$ & $1.85^{\mathrm{cd}}$ & $1.76^{\mathrm{a}}$ & $2.93^{\mathrm{abcd}}$ & $64.25 \pm 1.06^{b}$ & $7.14 \pm 0.40$ & $4.23 \pm 0.32 \mathrm{abc}$ \\
\hline & 20 & $1.12^{\text {bcde }}$ & $0.46^{\mathrm{d}}$ & $1.83^{\mathrm{cd}}$ & $1.73^{\mathrm{ab}}$ & $2.83^{\text {bcde }}$ & $65.10 \pm 0.14^{b}$ & $7.05 \pm 0.53$ & $4.14 \pm 0.44 \mathrm{abcd}$ \\
\hline & 25 & $1.15^{\mathrm{abc}}$ & $0.47^{\mathrm{d}}$ & $1.82^{\mathrm{d}}$ & $1.69^{a b}$ & $2.65^{\mathrm{e}}$ & $67.60 \pm 0.85^{a}$ & $7.48 \pm 0.88$ & $4.56 \pm 0.39 \mathrm{abc}$ \\
\hline
\end{tabular}

JMB: bran pulverized by jet mill, RWF: refined wheat flour, HMB: bran pulverized by hammer mill. C1: an objective value of $1.1 \mathrm{Nm}$ on average, C2: the lowest viscosity of the dough after the start of heating, C3: the starch gelatinization and represents the maximum torque after C2, C4: stability, C5: the torque value that appears after cooling the dough and observing starch degradation. All values are means of two replications \pm standard deviation. $*, * *, * * *$ significantly differ at $p \leq 0.01,0.05,0.001$, respectively. Different characters (a-e) in the same column indicate a significant difference at $p \leq 0.05$.

The dough development time of RWF was the shortest, and it increased as more bran was added. Fiber in the bran might prevent the gluten development of the dough $[29,30]$. However, no difference in dough stability was found among the samples. Dough characteristics such as water uptake, dough development time, and stability are known to be related to protein content and quality [31].

As shown in Table 3, the C2 and C 3 values of the HMB significantly increased with the substitution ratio of bran, and the JMB was not significantly different from the RWF. The C2 is associated with protein weakening, and the $\mathrm{C} 3$ is associated with gelatinization, which indicates a viscosity peak. Reduced gliadin and glutenin contents in bran might promote gluten weakening [16]. However, no difference was found in $\mathrm{C} 2$ and $\mathrm{C} 3$ of JMB with the substitution ratio of bran. The C4 and C5 showed a tendency to decrease as the bran substitution ratio increased. The content of bran and water absorption increase proportionally, which delays the retrogradation of starch [32]. Banu et al. [16] reported that the index of retrogradation decreases as the content of wheat bran increases. In addition, Koksel et al. [32] reported that the specific volume of breads increases with the value of C4 and C5.

\subsection{Characteristics of Bread}

Data on the specific volume, crumb hardness, and color of bread made with various substitution ratios $(0 \%, 5 \%, 10 \%, 15 \%, 20 \%$, and $25 \%)$ of pulverized bran are outlined in Table 4 . Depending on the replacement ratio of $\mathrm{HMB}$ or JMB, a significant difference was found in the specific volume of the bread. The specific volume of bread made with $5 \%$ and $10 \% \mathrm{HMB}$ or JMB substituted flour was significantly higher than that of the RWF, which was used as a control in this study. On the other hand, the bread made with $\geq 15 \% \mathrm{HMB}$ or JMB was low in specific volume, implying decreased baking quality when the bran was greater than $15 \%$. Noort et al. [33] reported increased adverse effects on bread-making when the particle size of bran decreased. The results of this study confirm previous reports, but only when $>15 \%$ of bran is used. The smaller particle size of wheat bran results in a higher surface area, thereby enhancing the fiber-protein interaction [33]. Hemdane et al. [6] reported that ferulic acid monomers bonding to the insoluble cell wall material may interfere with gluten network formation and have an adverse effect on baking. The results of this study showed that the volume of bread properly increased with $\leq 10 \% \mathrm{HMB}$ or JMB substituted flour, even with the very small particle size bran, implying that volume is more affected by wheat variety than by particle size. In other studies, the addition of barley bran and rice bran increased the loaf volume of bread [34,35]. Among the lipids in the wheat bran, glycolipid binds with glutenin to help increase the bread volume [36,37]. Previous reports found that different effects of wheat bran depend on the type of wheat [38-41]. 
Table 4. Specific volume (SV), crumb hardness, and color characteristics of breads made with flour substituted with HMB or JMB at various levels $(0 \%, 5 \%, 10 \%, 15 \%, 20 \%$, and $25 \%)$.

\begin{tabular}{ccccccc}
\hline \multirow{2}{*}{$\begin{array}{c}\text { Type of } \\
\text { Bran }\end{array}$} & \multirow{2}{*}{ Bran (\%) } & \multicolumn{2}{c}{ Bread } & \multicolumn{3}{c}{ Color of Crumb } \\
\cline { 2 - 6 } & & $\mathbf{S V ~ ( m L / g ) ~}^{* * *}$ & Hardness (N) ${ }^{* * *}$ & $\mathbf{L}^{* * *}$ & $\mathbf{a}^{* * *}$ & $\mathbf{b}^{* * *}$ \\
\hline RWF & 0 & $3.12 \pm 0.07^{\mathrm{c}}$ & $7.22 \pm 0.23^{\mathrm{de}}$ & $80.93 \pm 0.80^{\mathrm{a}}$ & $-0.64 \pm 0.11^{\mathrm{g}}$ & $14.49 \pm 0.14^{\mathrm{f}}$ \\
\hline \multirow{3}{*}{ HMB } & 5 & $3.53 \pm 0.05^{\mathrm{a}}$ & $4.36 \pm 0.03^{\mathrm{e}}$ & $74.48 \pm 1.25^{\mathrm{ab}}$ & $1.44 \pm 0.36^{\text {ef }}$ & $18.22 \pm 0.73^{\mathrm{e}}$ \\
& 10 & $3.42 \pm 0.06^{\mathrm{b}}$ & $4.81 \pm 0.08^{\mathrm{e}}$ & $73.89 \pm 0.40^{\mathrm{b}}$ & $2.13 \pm 0.21^{\mathrm{e}}$ & $18.94 \pm 0.77^{\mathrm{e}}$ \\
& 15 & $3.01 \pm 0.02^{\mathrm{d}}$ & $8.17 \pm 0.14^{\mathrm{d}}$ & $72.79 \pm 0.51^{\mathrm{bc}}$ & $2.97 \pm 0.36^{\mathrm{d}}$ & $22.15 \pm 0.97^{\mathrm{cd}}$ \\
& 20 & $2.98 \pm 0.02^{\mathrm{d}}$ & $8.23 \pm 0.33^{\mathrm{d}}$ & $69.62 \pm 0.75^{\mathrm{bc}}$ & $4.46 \pm 0.17^{\mathrm{b}}$ & $24.63 \pm 0.47^{\mathrm{ab}}$ \\
& 25 & $2.62 \pm 0.02^{\mathrm{f}}$ & $21.49 \pm 0.56^{\mathrm{b}}$ & $65.92 \pm 0.66^{\mathrm{c}}$ & $5.65 \pm 0.19^{\mathrm{a}}$ & $25.31 \pm 0.20^{\mathrm{a}}$ \\
\hline \multirow{3}{*}{ JMB } & 5 & $3.49 \pm 0.01^{\mathrm{ab}}$ & $5.90 \pm 0.25^{\mathrm{de}}$ & $74.75 \pm 0.14^{\mathrm{ab}}$ & $1.15 \pm 0.24^{\mathrm{f}}$ & $18.85 \pm 0.76^{\mathrm{e}}$ \\
& 10 & $3.44 \pm 0.02^{\mathrm{ab}}$ & $6.03 \pm 0.20^{\mathrm{de}}$ & $71.19 \pm 6.81^{\mathrm{bc}}$ & $2.12 \pm 0.19^{\mathrm{e}}$ & $21.47 \pm 0.28^{\mathrm{d}}$ \\
& 15 & $2.67 \pm 0.01^{\text {ef }}$ & $15.12 \pm 0.30^{\mathrm{c}}$ & $71.09 \pm 2.27^{\mathrm{bc}}$ & $3.67 \pm 0.29^{\mathrm{cd}}$ & $23.32 \pm 0.72^{\mathrm{bc}}$ \\
& 20 & $2.77 \pm 0.02^{\mathrm{e}}$ & $14.88 \pm 3.52^{\mathrm{c}}$ & $70.11 \pm 0.55^{\mathrm{bc}}$ & $4.32 \pm 0.20^{\mathrm{bc}}$ & $24.77 \pm 0.09^{\mathrm{ab}}$ \\
& 25 & $2.02 \pm 0.01^{\mathrm{g}}$ & $26.10 \pm 0.49^{\mathrm{a}}$ & $66.50 \pm 0.63^{\mathrm{c}}$ & $5.85 \pm 0.24^{\mathrm{a}}$ & $25.60 \pm 0.44^{\mathrm{a}}$ \\
\hline
\end{tabular}

JMB: bran pulverized by jet mill, RWF: refined wheat flour, HMB: bran pulverized by hammer mill. All values are means of three replications \pm standard deviation. ${ }^{* * *}$ Significantly differ at $p \leq 0.001$. Different characters (a-g) in the same column indicate a significant difference at $p \leq 0.05$.

The hardness of the bread increased significantly with $25 \% \mathrm{HMB}$ or $15 \%, 20 \%$, and $25 \%$ JMB substitution (Table 4). Previous reports [32,42,43] showed that the higher amount and the smaller particle size of bran resulted in a harder crumb. The results of this study confirm that bread with JMB, which is small in particle size, is harder than bread with HMB when the substitution is $\geq 15 \%$. As the substitution ratio increased, the $L$ value significantly decreased, and a and $b$ values tended to increase (see Table 4).

The scanning electron microscopy (SEM) images of dough and bread made with various substitution ratios $(0 \%, 5 \%, 10 \%, 15 \%, 20 \%$, and $25 \%$ ) of HMB or JMB are in Figure 2 . The SEM image showed a more continuous gluten structure in dough with 5\% and 10\% HMB or JMB than in the control sample and dough with $\geq 20 \%$ HMB or JMB. This implies that $<10 \%$ bran enhances baking property, which may be because of components such as phospholipids.

A
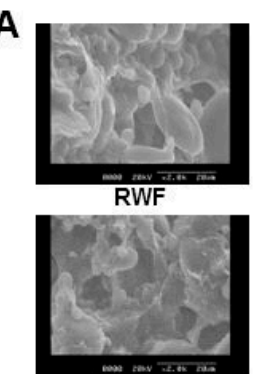

HMB 15

B

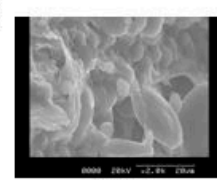

RWF

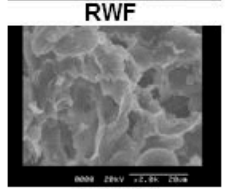

JMB 15

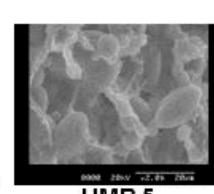

HMB 5

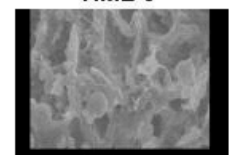

HMB 20

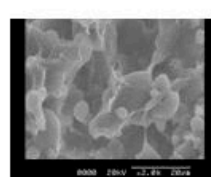

JMB 5

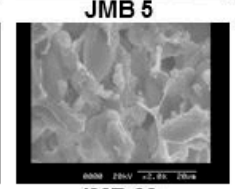

JMB 20

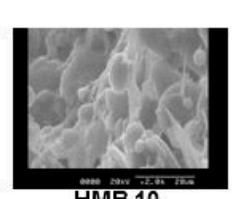

HMB 10

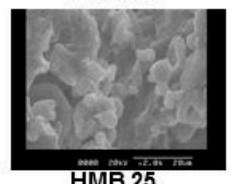

HMB 25

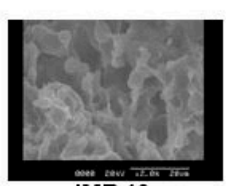

JMB 10

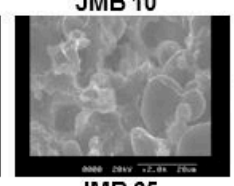

JMB 25

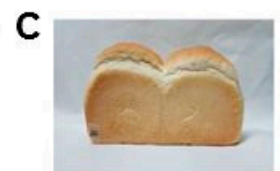

Refined wheat flour (RWF)

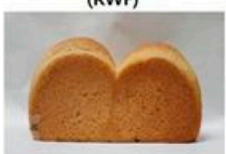

$85 \%$ RWF $+15 \%$ HMB

\section{D}

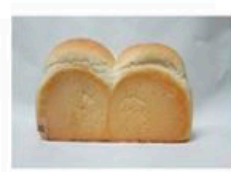

Refined wheat flour

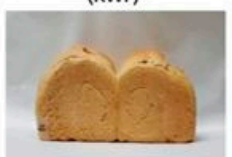

$85 \%$ RWF + $15 \%$ JMB

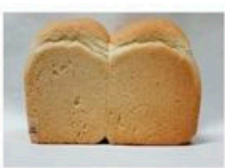

$95 \%$ RWF $+5 \%$ HMB

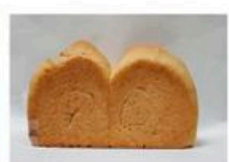

$80 \%$ RWF $+20 \%$ HMB

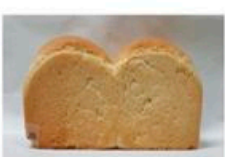

$95 \%$ RWF + 5\% JMB

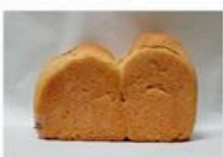

$80 \%$ RWF + $20 \%$ JMB

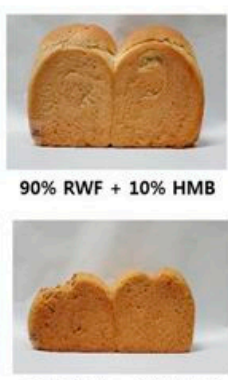

$75 \%$ RWF + $25 \%$ HMB

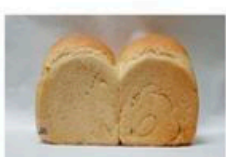

$90 \%$ RWF + $10 \%$ JMB

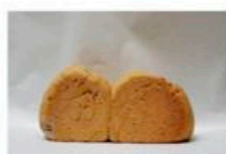

$75 \%$ RWF $+25 \%$ JMB

Figure 2. Scanning electron microscopy $(\mathrm{SEM}, \times 2000)$ images of dough and bread made with various substitution ratios $(0 \%, 5 \%, 10 \%, 15 \%, 20 \%, 25 \%)$ of $(\mathbf{A}, \mathbf{C})$ HMB or (B,D) JMB. HMB: bran pulverized by hammer mill, JMB: bran pulverized by jet mill. 


\subsection{Antioxidant Activity of Bread}

The antioxidant activity of bread with bran was evaluated by ORAC and ABTS and the results are in Figure 3. ORAC and ABTS are used to measure potential antioxidant capacity by measuring the defense from a free radical attack [44]. As shown in Figure 3, the antioxidant activity was significantly increased with the substitution ratio of bran. In both $\mathrm{HMB}$ and JMB, the antioxidant activity was the highest at $25 \%$ of bran substitution ratio. Many enzymes in wheat are involved in antioxidant activity, and most of these enzymes are distributed in bran [45]. Gunenc et al. [46] reported antioxidant activity in bread with $30 \%$ wheat bran and $2 \%$ alkylresorcinol extract.

A

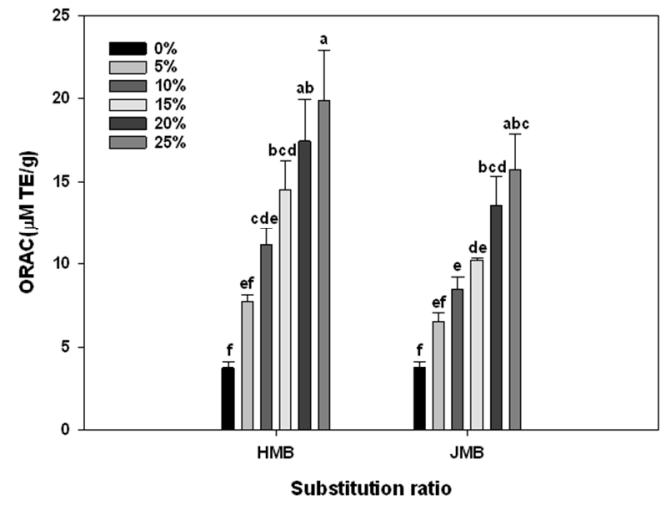

B

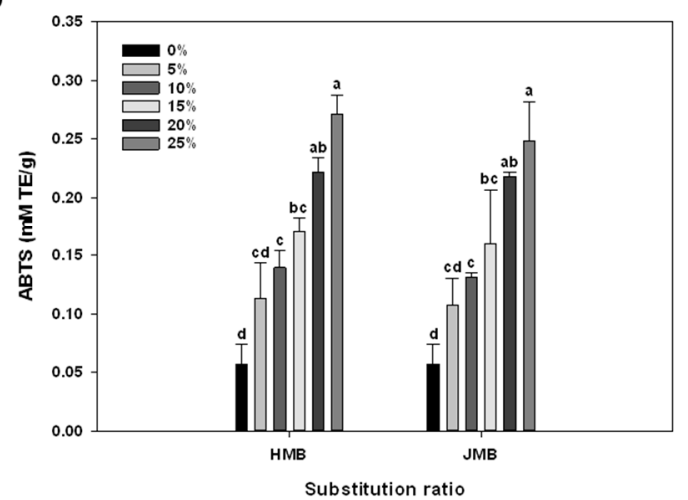

Figure 3. Effects of various substitution ratios of $\mathrm{HMB}$ or JMB on antioxidant activity of breads by (A) oxygen radical absorbance capacity (ORAC) and (B) 2, 2'-Azino-bis (3-ethylbenz-thiazoline-6-sulfonic acid (ABTS) assay. HMB: bran pulverized by hammer mill, JMB: bran pulverized by jet mill. Bars with different characters indicate a significant difference at $p \leq 0.05$.

Antioxidants in cereals are mostly phenolic compounds in the form of phenolic acids and insoluble bound ferulic acid, and they are concentrated in wheat bran [47]. The ferulic acid in particular is typically present in a variety of plants, particularly wheat in the form that is combined with the cell wall. Ferulic acid is known to have an antioxidant effect as a mechanism to remove free radicals by donating electrons or attacking free radicals in structure [48]. The addition of rice bran at $5 \%-10 \%$ improved the physical and antioxidant activity of rice bread [49]. Taken together, the antioxidant activity of bread increased with the addition of cereal bran.

\section{Conclusions}

The effects of the substitution ratio $(0 \%-25 \%)$ and milling type of bran on the characteristics of dough and bread were investigated. In this study, flour substituted with $<10 \%$ bran enhanced the bread regardless of the milling method quality by increasing specific volume and decreasing the hardness of bread. The addition of wheat bran with a large particle size milled with a hammer mill improved bread quality without affecting color or hardness, which could affect preference more effectively than the jet mill. HMB was more suitable for bread-making than JMB, implying a detrimental effect of the fine size of JMB. However, antioxidant activity increased by increasing the substitution ratio of bran regardless of the bran milling method. Overall, the results of this study imply that the proper addition of wheat bran enhances the physical and nutritional quality of bakery products.

Author Contributions: Conceptualization, S.S.K.; methodology, M.J.K.; validation, M.J.K. and H.S.K.; formal analysis, D.L.; investigation, M.J.K.; data curation, D.L. and H.S.K.; writing-original draft preparation, D.L.; writing-review and editing, S.S.K.; visualization, D.L. and M.J.K.; supervision, S.S.K.; project administration, M.J.K.; funding acquisition, S.S.K. All authors have read and agreed to the published version of the manuscript.

Funding: This research was funded by Korea Institute of Planning and Evaluation for Technology in Food, Agriculture, Forestry (IPET) grant number 317019-4. 
Acknowledgments: This research was funded by IPET through Agri-Bio industry Technology Development Program, funded by Ministry of Agriculture, Food and Rural Affairs (MAFRA) (317019-4).

Conflicts of Interest: The authors declare no conflicts of interest.

\section{References}

1. Dewettinck, K.; Van Bockstaele, F.; Kühne, B.; Van de Walle, D.; Courtens, T.; Gellynck, X. Nutritional value of bread: Influence of processing, food interaction and consumer perception. J. Cereal Sci. 2008, 48, 243-257. [CrossRef]

2. Geng, P.; Harnly, J.M.; Chen, P. Differentiation of whole grain from refined wheat (T. aestivum) flour using lipid profile of wheat bran, germ, and endosperm with UHPLC-HRAM mass spectrometry. J. Agric. Food Chem. 2015, 63, 6189-6211. [CrossRef] [PubMed]

3. Anderson, J.W.; Smith, B.M.; Gustafson, N.J. Health benefits and practical aspects of high-fiber diets. Am. J. Clin. Nutr. 1994, 59, 1242S-1247S. [CrossRef] [PubMed]

4. Karaoğlu, M.M. Effect of baking procedure and storage on the pasting properties and staling of part-baked and rebaked wheat bran bread. Int. J. Food Sci. Tech. 2006, 41, 77-82.

5. Hoseney, R.C. Principles of Cereal Science and Technology; American Association of Cereal Chemists (AACC): St Paul, MN, USA, 1994.

6. Hemdane, S.; Jacobs, P.J.; Dornez, E.; Verspreet, J.; Delcour, J.A.; Courtin, C.M. Wheat (triticum aestivum l.) bran in bread making: A critical review. Compr 2016, 15, 28-42. [CrossRef]

7. Liu, R.H. Whole grain phytochemicals and health. J. Cereal Sci. 2007, 46, 207-219. [CrossRef]

8. Sobota, A.; Rzedzicki, Z.; Zarzycki, P.; Kuzawińska, E. Application of common wheat bran for the industrial production of high-fibre pasta. Int. J. Food Sci. Tech. 2015, 50, 111-119. [CrossRef]

9. Ciccoritti, R.; Terracciano, G.; Cammerata, A.; Sgrulletta, D.; Del Frate, V.; Gazza, L.; Nocente, F. Hydrothermal grain pre-processing and ultra-fine milling for the production of durum wheat flour fractions with high nutritional value. Food Sci. Technol. Int. 2018, 24, 242-250. [CrossRef]

10. Ciccoritti, R.; Nocente, F.; Sgrulletta, D.; Gazza, L. Cooking quality, biochemical and technological characteristics of bran-enriched pasta obtained by a novel pasta-making process. LWT 2019, 101, 10-16. [CrossRef]

11. Song, X.; Zhu, W.; Pei, Y.; Ai, Z.; Chen, J. Effects of wheat bran with different colors on the qualities of dry noodles. J. Cereal Sci. 2013, 58, 400-407. [CrossRef]

12. Kim, B.K.; Chun, Y.G.; Cho, A.R.; Park, D.J. Reduction in fat uptake of doughnut by microparticulated wheat bran. Int. J. Food Sci. Nutr. 2012, 63, 987-995. [CrossRef] [PubMed]

13. Sozer, N.; Cicerelli, L.; Heiniö, R.-L.; Poutanen, K. Effect of wheat bran addition on in vitro starch digestibility, physico-mechanical and sensory properties of biscuits. J. Cereal Sci. 2014, 60, 105-113. [CrossRef]

14. Sidhu, J.S.; Al-Hooti, S.N.; Al-Saqer, J.M. Effect of adding wheat bran and germ fractions on the chemical composition of high-fiber toast bread. Food Chem. 1999, 67, 365-371. [CrossRef]

15. Inoue, T.; OSATAKE, H. A new drying method of biological specimens for scanning electron microscopy: The t-butyl alcohol freeze-drying method. Arch. Histol. Cytol. 1988, 51, 53-59. [PubMed]

16. Banu, I.; Stoenescu, G.; Ionescu, V.S.; Aprodu, I. Effect of the addition of wheat bran stream on dough rheology and bread quality. Ann. Univ. Dunarea Jos Galati. Fascicle VI. Food Technol. 2012, 36, 39.

17. Lim, H.S.; Park, S.H.; Ghafoor, K.; Hwang, S.Y.; Park, J. Quality and antioxidant properties of bread containing turmeric (Curcuma longa L.) cultivated in south korea. Food Chem. 2011, 124, 1577-1582. [CrossRef]

18. Rosa, N.N.; Barron, C.; Gaiani, C.; Dufour, C.; Micard, V. Ultra-fine grinding increases the antioxidant capacity of wheat bran. J. Cereal Sci. 2013, 57, 84-90. [CrossRef]

19. Moore, J.; Hao, Z.G.; Zhou, K.Q.; Luther, M.; Costa, J.; Yu, L.L. Carotenoid, tocopherol, phenolic acid, and antioxidant properties of maryland-grown soft wheat. J. Agric. Food Chem. 2005, 53, 6649-6657. [CrossRef]

20. Saravacos, G.D.; Kostaropoulos, A.E. Handbook of Food Processing Equipment, 2nd ed.; Springer: New York, NY, USA, 2002; pp. 149-232.

21. Ahmed, J.; Al-Jassar, S.; Thomas, L. A comparison in rheological, thermal, and structural properties between indian basmati and egyptian giza rice flour dispersions as influenced by particle size. Food Hydrocoll. 2015, 48, 72-83. [CrossRef] 
22. Murali, S.; Govindan, V. Shadow detection and removal from a single image using lab color space. Cybern. Inf. Technol. 2013, 13, 95-103. [CrossRef]

23. Choi, I.; Kang, C.S.; Lee, C.K.; Kim, S.L. Classification of 31 korean wheat (triticum aestivum 1.) cultivars based on the chemical compositions. Prev. Nutr. Food Sci. 2016, 21, 393. [CrossRef] [PubMed]

24. Schmiele, M.; Jaekel, L.Z.; Patricio, S.M.C.; Steel, C.J.; Chang, Y.K. Rheological properties of wheat flour and quality characteristics of pan bread as modified by partial additions of wheat bran or whole grain wheat flour. Int. J. Food Sci. Tech. 2012, 47, 2141-2150. [CrossRef]

25. Chen, J.S.; Fei, M.J.; Shi, C.L.; Tian, J.C.; Sun, C.L.; Zhang, H.; Ma, Z.; Dong, H.X. Effect of particle size and addition level of wheat bran on quality of dry white chinese noodles. J. Cereal Sci. 2011, 53, 217-224. [CrossRef]

26. Roozendaal, H.; Abu-Hardan, M.; Frazier, R.A. Thermogravimetric analysis of water release from wheat flour and wheat bran suspensions. J. Food Eng. 2012, 111, 606-611. [CrossRef]

27. Choi, U.K.; Yoo, B.H.; Son, D.H.; Kwon, D.J.; Kim, M.H.; Kim, Y.H. Rheological properties of dough added with barley bran. Korean J. Food Sci. Technol. 2005, 37, 751-756.

28. Gomez, M.; Ronda, F.; Blanco, C.A.; Caballero, P.A.; Apesteguia, A. Effect of dietary fibre on dough rheology and bread quality. Eur. Food Res. Technol. 2003, 216, 51-56. [CrossRef]

29. Gómez, M.; Jiménez, S.; Ruiz, E.; Oliete, B. Effect of extruded wheat bran on dough rheology and bread quality. LWT 2011, 44, 2231-2237. [CrossRef]

30. Wang, J.; Rosell, C.M.; de Barber, C.B. Effect of the addition of different fibres on wheat dough performance and bread quality. Food Chem. 2002, 79, 221-226. [CrossRef]

31. Dubat, A. A new aacc international approved method to measure rheological properties of a dough sample. Cereal Foods World 2010, 55, 150. [CrossRef]

32. Koksel, H.; Kahraman, K.; Sanal, T.; Ozay, D.S.; Dubat, A. Potential utilization of mixolab for quality evaluation of bread wheat genotypes. Cereal Chem. 2009, 86, 522-526. [CrossRef]

33. Noort, M.W.; van Haaster, D.; Hemery, Y.; Schols, H.A.; Hamer, R.J. The effect of particle size of wheat bran fractions on bread quality-evidence for fibre-protein interactions. J. Cereal Sci. 2010, 52, 59-64. [CrossRef]

34. Phimolsiripol, Y.; Mukprasirt, A.; Schoenlechner, R. Quality improvement of rice-based gluten-free bread using different dietary fibre fractions of rice bran. J. Cereal Sci. 2012, 56, 389-395. [CrossRef]

35. Choi, U.-K. Effect of barley bran flour addition on the quality of bread. Korean J. Food Sci. Technol. 2005, 37, 746-750.

36. Hoseney, R.; Finney, K.; Pomeranz, Y. Functional (breadmaking) and biochemical properties of wheat flour components. Vi. Gliadin-lipid-glutenin interaction in wheat gluten. Cereal Chem. 1970, 47, 135-140.

37. Helmerich, G.; Koehler, P. Functional properties of individual classes of phospholipids in breadmaking. J. Cereal Sci. 2005, 42, 233-241. [CrossRef]

38. Özboy, Ö.; Köksel, H. Unexpected strengthening effects of a coarse wheat bran on dough rheological properties and baking quality. J. Cereal Sci. 1997, 25, 77-82. [CrossRef]

39. Nelles, E.M.; Randall, P.G.; Taylor, J.R. Improvement of brown bread quality by prehydration treatment and cultivar selection of bran. Cereal Chem. 1998, 75, 536-540. [CrossRef]

40. De Kock, S.; Taylor, J.; Taylor, J. Effect of heat treatment and particle size of different brans on loaf volume of brown bread. LWT 1999, 32, 349-356. [CrossRef]

41. Seyer, M.È; Gélinas, P. Bran characteristics and wheat performance in whole wheat bread. Int. J. Food Sci. Tech. 2009, 44, 688-693. [CrossRef]

42. Sanz-Penella, J.M.; Laparra, J.M.; Sanz, Y.; Haros, M. Influence of added enzymes and bran particle size on bread quality and iron availability. Cereal Chem. 2012, 89, 223-229. [CrossRef]

43. De La Hera, E.; Rosell, C.M.; Gomez, M. Effect of water content and flour particle size on gluten-free bread quality and digestibility. Food Chem. 2014, 151, 526-531. [CrossRef] [PubMed]

44. Dziki, D.; Rozylo, R.; Gawlik-Dziki, U.; Swieca, M. Current trends in the enhancement of antioxidant activity of wheat bread by the addition of plant materials rich in phenolic compounds. Trends Food Sci Tech 2014, 40, 48-61. [CrossRef]

45. Rani, K.U.; Rao, U.J.S.P.; Leelavathi, K.; Rao, P.H. Distribution of enzymes in wheat flour mill streams. J. Cereal Sci. 2001, 34, 233-242. [CrossRef] 
46. Gunenc, A.; Tavakoli, H.; Seetharaman, K.; Mayer, P.M.; Fairbanks, D.; Hosseinian, F. Stability and antioxidant activity of alkyresorcinols in breads enriched with hard and soft wheat brans. Food Res. Int. 2013, 51, 571-578. [CrossRef]

47. Hatcher, D.; Kruger, J. Simple phenolic acids in flours prepared from canadian wheat: Relationship to ash content, color, and polyphenol oxidase activity. Cereal Chem. 1997, 74, 337-343. [CrossRef]

48. Srinivasan, M.; Sudheer, A.R.; Menon, V.P. Ferulic acid: Therapeutic potential through its antioxidant property. J. Clin. Biochem. Nutr. 2007, 40, 92-100. [CrossRef] [PubMed]

49. Sairam, S.; Krishna, A.G.G.; Urooj, A. Physico-chemical characteristics of defatted rice bran and its utilization in a bakery product. J. Food Sci. Tech. Mys 2011, 48, 478-483. [CrossRef]

(C) 2020 by the authors. Licensee MDPI, Basel, Switzerland. This article is an open access article distributed under the terms and conditions of the Creative Commons Attribution (CC BY) license (http://creativecommons.org/licenses/by/4.0/). 